\section{Association of cadmium exposure with rapidly progressive emphysema in a smoker}

D Leduc, P de Francquen, D Jacobovitz, R Vandeweyer, R Lauwerys, P De Vuyst

\begin{abstract}
Rapidly progressive emphysema developed in a 59 year old smoker after exposure to cadmium fumes in a factory. Very high levels of cadmium in air sampled at the workplace and in the patient's blood, urine, and lung tissue confirmed massive exposure. These data strongly suggest an association between the patient's cadmium exposure and the development of emphysema.
\end{abstract}

(Thorax 1993;48:570-571)

Cadmium is a byproduct of the zinc and lead industry. It is mainly used for metal plating and for the production of batteries, pigments, plastic stabilisers, and some alloys. Chronic inhalation of cadmium fumes and dusts has been associated with emphysema. ${ }^{1-5}$ Other markers of chronic cadmium intoxication are renal failure, proteinuria and, in the advanced stage, osteomalacia. ${ }^{6} \mathrm{We}$ report the case of a patient who was exposed to very high levels of cadmium and who presented with rapidly progressive emphysema.

\section{Case report}

A 59 year old man had smoked a mean of 20 cigarettes daily since the age of 16 . He had no past history of respiratory disease. In 1975 he became a furnace worker in a plant producing cadmium salts and oxides. No chest radiograph was taken at that time. During the following four years he was exposed to a very dusty environment and almost every day handled, without protection, cadmium pieces coming out from the furnaces.

In the course of a medical survey carried out in 1979, airborne cadmium levels were measured in the workplace and showed mean values of $446 \mu \mathrm{g} / \mathrm{m}^{3}$ (range 164-1192 $\mu \mathrm{g} / \mathrm{m}^{3}$ during day) equal to about nine times the current threshold limit value of $50 \mu \mathrm{g} / \mathrm{m}^{3}$. Air sampling was carried out with a personal air sampler equipped with a filter holder. After treatment with nitric acid the filter was analysed by flameless atomic absorption spectroscopy. The cumulative integrated exposure to cadmium was estimated at $1600 \mu \mathrm{g} / \mathrm{m}^{3} \times$ years.

In 1979 clinical examination of the patient showed slight renal failure (serum creatinine, $1.6 \mathrm{mg} / \mathrm{dl}$; normal, $0.95-1.2 \mathrm{mg} / \mathrm{dl}$; creatinine clearance, $75 \mathrm{ml} / \mathrm{min}$ ) and elevated cadmium levels in blood and urine (table). Moderate proteinuria was also present $(127 \mathrm{mg} / 100 \mathrm{ml})$ with $\beta_{2}$ microglobulinuria (2002 $\gamma / 1$; normal $<300 \gamma / 1)$. He had no respiratory symptoms but his chest radiograph and lung function tests were consistent with pulmonary emphysema (table). The serum $\alpha_{1}$-antitrypsin level was normal (313 mg/dl) and his Pi phenotype was MM.

The patient was considered to have an occupational disease and was told to stop work. During the following 10 years, blood and urine cadmium levels, chest radiography, and lung function were regularly monitored. The patient first noticed exertional dyspnoea in 1983, and this was incapacitating by 1989 . Severe impairment of lung function (table) and radiographic appearance of emphysema (fig 1) were present at that time. Chest radiography also disclosed a nodule in the right pulmonary field (fig 1) and a computed tomographic scan suggested a neoplasm. Repeated bronchoscopic procedures failed to confirm a diagnosis of lung cancer but, since there was no evidence of metastases nor disease of the mediastinal lymph nodes, the right middle lobe was removed. Histological examination of the tumour showed a poorly differentiated adenocarcinoma surrounded by advanced panacinar emphysema and considerable dilatations of centrilobular structures (fig 2). There was no interstitial fibrosis.

The mean concentration of cadmium in the lung parenchyma was $580 \mu \mathrm{g} / \mathrm{g}$ dry tissue compared with a mean of $14 \mu \mathrm{g} / \mathrm{g}$ in three unexposed controls matched for age, sex, and smoking habits who had also undergone resection of a bronchial carcinoma.

\section{Discussion}

Since Friberg first suggested a relationship between cadmium exposure and emphysema

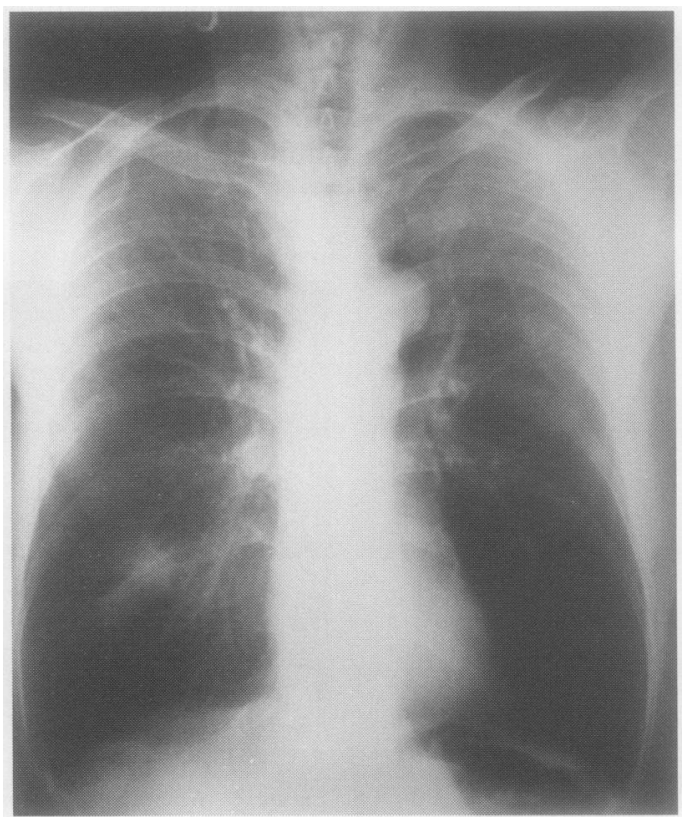

Figure 1 Chest radiograph in 1989 showing changes consistent with emphysema with hyperinflation of both lungs and reduced bronchovascular structures at the bases. An ill defined nodule is present in the middle lobe.
Received 19 September 1991 Accepted 5 January 1992

Department of Chest
Medicine, Erasme
Hospital, Free
University of Brussels,
Belgium
D Leduc
P de Francquen
D Jacobovitz
R Vandeweyer
P De Vuyst
Occupational Diseases
Fund, Brussels,
Belgium
R Vandeweyer
P De Vuyst
Industrial and
Medical Toxicology
Unit, Catholic
University of Louvain,
Belgium
R Lauwerys
Reprint requests to:
Dr D Leduc
Received 19 September
1991
Accepted 5 January 1992


Cadmium levels in blood and urine and results of lung function tests

\begin{tabular}{|c|c|c|c|c|}
\hline & 1979 & 1980 & 1983 & 1989 \\
\hline $\begin{array}{l}\text { Cadmium in blood }(\mu \mathrm{g} / 1 \text {; normal }<10) \\
\text { Cadmium in urine }(\mu \mathrm{g} / 1 ; \text { normal }<10) \\
\text { Lung function tests }\end{array}$ & $\begin{array}{r}97 \\
170\end{array}$ & $\begin{array}{l}55 \\
77\end{array}$ & $\begin{array}{l}28 \\
48\end{array}$ & $\begin{array}{l}18 \\
35\end{array}$ \\
\hline $\begin{array}{l}\text { Lung function tests } \\
\text { Vital capacity (l) } \\
\text { FEV }(\text { (l) } \\
\text { Total lung capacity (l) } \\
\text { Residual volume (l) } \\
\text { TLCo }(\mathrm{ml} / \mathrm{min} / \mathrm{mm} \mathrm{Hg})\end{array}$ & $\begin{array}{l}\bar{z} \\
\bar{z}\end{array}$ & $\begin{array}{r}3 \cdot 9 \\
2 \cdot 3 \\
5 \cdot 9 \\
2 \cdot 1 \\
20\end{array}$ & $\begin{array}{l}3 \cdot 2 \\
1.6 \\
6 \cdot 0 \\
2 \cdot 8 \\
22\end{array}$ & $\begin{array}{c}2 \cdot 7(57 \%) \\
0.9(26 \%) \\
7 \cdot 2(106 \%) \\
4.5(194 \%) \\
13(45 \%)\end{array}$ \\
\hline
\end{tabular}

Values in parentheses are percentage of predicted values

FEV $_{1}$ - forced expiratory volume in one second; TLCO-carbon monoxide transfer factor.

in $1951,{ }^{1}$ numerous epidemiological studies have been devoted to this problem. Results have been controversial, with some studies showing a relationship ${ }^{1-5}$ while others have not. ${ }^{78}$ This controversial issue has recently been settled by the results of a study of a large group of 101 workers and ex-workers from a cadmium alloy factory in England. ${ }^{5}$ In this study there was clear functional (ventilatory function and diffusing capacity) and radiological evidence of emphysema in the exposed subjects compared with appropriate controls, and a positive relationship was seen between effect and dose.

The evidence suggests that cadmium was responsible, in part at least, for the development of emphysema in our patient. The patient also had proteinuria and renal impairment, other common signs of chronic cadmium intoxication. The evolution of emphysema was exceptionally fast; the mean annual loss of $\mathrm{FEV}_{1}$ was $140 \mathrm{ml}$ which is unusual for emphysema in a smoker $\left(\triangle \mathrm{FEV}_{1}\right.$ $=80-120 \mathrm{ml} /$ year $)$ in the absence of $\alpha_{1}$-antitrypsin deficiency. ${ }^{9}$ The exposure to cadmium appears to have been very high as judged by cadmium levels in lung parenchyma, blood, urine, and at the workplace of the patient. The very high lung cadmium concentrations ( $580 \mu \mathrm{g} / \mathrm{g}$ dry tissue compared with the usual values in human lung tissue $0.64-1.48 \mu \mathrm{g} / \mathrm{g}$ dry tissue) ${ }^{10}$ were consistent with a very high cumulative exposure. During the 10 years of follow up the blood and urine concentrations of cadmium progressively decreased. The cadmium concentration in the lung in 1989 , however, was 150 times the values observed in control cases. Blood concentrations probably mainly reflect the average intake of cadmium during recent months whereas lung concentrations provide a direct assessment of the cadmium lung burden which is probably of more relevance for cadmium lung toxicity.

Our patient was also a smoker and tobacco might have had a synergistic effect, either by increasing the cadmium burden on the lung since cadmium is a constituent of tobacco, or indirectly by reducing lung clearance of cadmium. ${ }^{10}$

As far as we are aware this is the first time

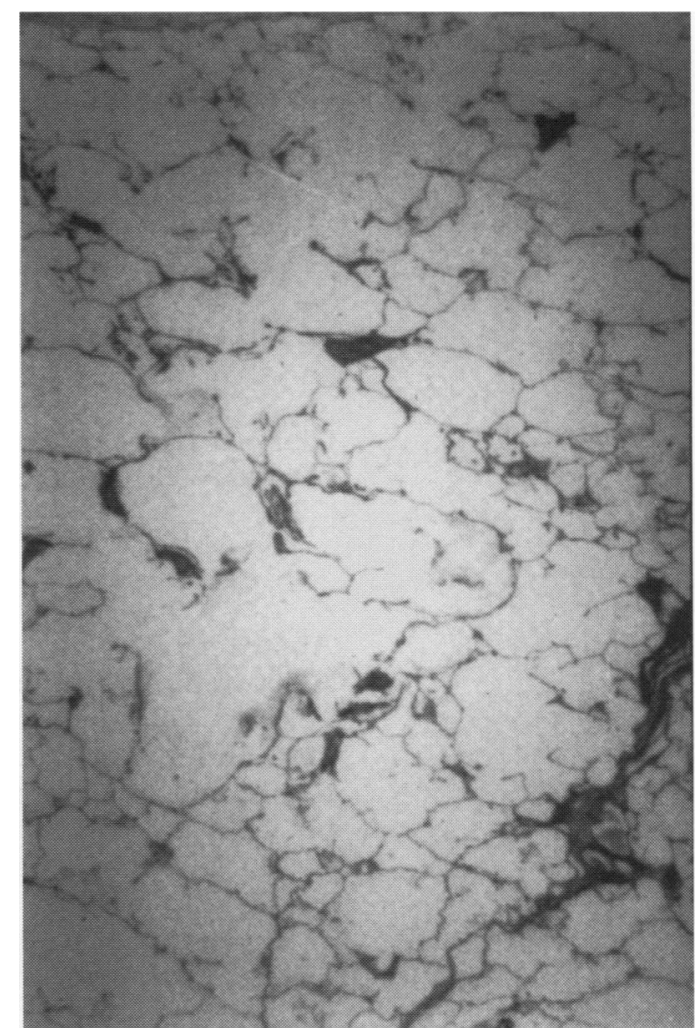

Figure 2 Histological section of the lung parenchyma showing centrilobular and panlobular emphysema.

that such a large exposure to and lung retention of cadmium have been documented in a patient with severe emphysema. This case supports the hypothesis of an aetiological role of cadmium fume inhalation in the development of emphysema.

1 Friberg L. Proteinuria and emphysema among workers exposed to cadmium and nickel dust in a storage battery plant. Proc Int Congr Ind Med 1948;9:641-4.

2 Bonnell JA. Emphysema and proteinuria in men casting copper-cadmium alloys. $\mathrm{Br} \mathcal{F}$ Ind $\mathrm{Med}$ 1955;12:181-7.

3 Kazantzis SG. Respiratory function in men casting cadmium alloys. Part I: Assessment of ventilatory function. Br 7 Ind Med 1956;13:30-6.

4 Gill PF. Respiratory function in a group of workers exposed to cadmium in Hobart. Proceedings of First International Cadmium Conference, San Francisco. Metal Bulletin Survey 1978:207-10.

5 Davison AG, Newman Taylor AJ, Darbyshire J, Chettle DR, Gutherie CJG, O'Malley D, et al. Cadmium fume inhalation and emphysema. Lancet 1988;i:663-7.

6 Bernard A, Lauwerys R. Effects of cadmium exposure in humans. In: Foulkes EC, ed. Handbook of experimental pharmacology. Berlin: Springer-Verlag; 1986;135-77.

7 Tsuchiya K. Proteinuria of workers exposed to cadmium fume. The relationship to concentration in the working environment. Arch Environ Health 1967;14:875-80.

8 Lauwerys R, Buchet JP, Roels H, Brouwers J, Stanescu D. Epidemiological survey of workers exposed to cadmium. Arch Environ Health 1974;28:145-8.

9 Burrows B, Earle RH. Course and prognosis of chronic obstructive lung disease. $N$ Engl $₹$ Med 1969; 280 397-404.

10 Kollmeier H, Seemann, J, Wittig P, Rotle G, Muller M. Cadmium in human lung tissue. Int Arch Occup Environ Health 1990;62:373-7. 